\title{
Pengaruh Kompetensi Terhadap Kinerja Pegawai Pada Badan Kepegawaian Dan Pengembangan Sumber Daya Manusia Kota Tasikmalaya
}

\author{
Ade Dony Firmansyah \\ Pascasarjana Ilmu Administrasi Negara, Sekolah Tinggi Ilmu Administrasi YPPT Priatim \\ Tasikmalaya \\ adonfirmansyah@ymail.com
}

\begin{abstract}
ABSTRAK
Badan Kepegawaian dan Pengembangan Sumber Daya Manusia Kota Tasikmalaya mempunyai tugas pokok melaksanakan fungsi penunjang urusan pemerintahan daerah di bidang kepegawaian, pendidikan dan pelatihan daerah. Realisasi persentase aparatur yang mengikuti pengembangan kompetensi masih belum mencapai target yang diharapkan.Dalam rangka pencapaian target pengembangan pegawai dan peningkatan pelayanan kepada pegawai diperlukan kinerja yang tinggi dari pegawai. Salah satu faktor dalam menunjang kinerja pegawai tersebut diperlukan kompetensi yang tinggi dari pegawai tersebut. Oleh karena itu tujuan penelitian ini bertujuan mengetahui seberapa besar pengaruh kompetesi yang dimiliki pegawai terhadap kinerja pegawai di Badan Kepegawaian dan Pengembangan Sumber Daya Manusia Kota Tasikmalaya.Penelitian ini menggunakan metode penelitian research eksplanatory. Responden penelitian ini yaitu pegawai di Badan Kepegawaian dan Pengembangan Sumber Daya Manusia Kota Tasikmalaya. Teknik analisis data dilakukan melalui uji regresi. Berdasarkan hasil penelitian menunjukan terdapat pengaruh yang kuat antara kompetesi terhadap kinerja pegawai di Badan Kepegawaian dan Pengembangan Sumber Daya Manusia Kota Tasikmalaya. Kesimpulan dari penelitian ini bahwa semua faktor yang terdiri dari kompetensi yaitu berorientasi prestasi dan tindakan, membantu dan melayani orang lain, kemampuan mempengaruhi dan menciptakan dampak, kemampuan manajerial, kemampuan kognisi dan kemampuan efektivitas pribadi memiliki pengaruh terhadap kinerja pegawai di Badan Kepegawaian dan Pengembangan Sumber Daya Manusia Kota Tasikmalaya.

Kata Kunci: Kompetensi, Kinerja, Pegawai.
\end{abstract}

\begin{abstract}
The council of employee affairs and human resource development Tasikmalaya City has main task to carry out supportive function of regional government issue in the field of regional employee affairs, education, and training. The realization of percentage of officials attending competency development has not yet reached the expected target. Achieving the target of developing the employees and improving the service on them needs high performance of the employees. One of the factors that supports the employees' high performance is high competency of the employees themselves. Therefore the aim of this research is to know how big the effects of competency owned by the employee on the performance of the employee at the council of employee affairs and human resource development kota tasikmalaya. The method used in this research is research explanatory. The respondents of the research are the employees of the council of employee affairs and human resource development Tasikmalaya City. The data analysis technique is implemented through the regression test. Based on the result of the research it is concluded that there is a strong influence between competency against the performance of employee at the council of employee affairs and human resource development kota tasikmalaya. The conclusion of the research is that all factors included in the competency are achievement and action oriented, helpful and serving others, able to influence and create impact, able to manage, able to have cognition and self effectiveness, able to have the influence on the performance of the employees at the council of employee affairs and human resource development Tasikmalaya City.
\end{abstract}

Keywords: Competency, Performance, Employees. 


\section{PENDAHULUAN}

Pembinaan Pegawai Negeri Sipil di daerah kabupaten kota di Indonesia dilakukan oleh Badan Kepegawaian dan Pengembangan Sumber Daya Manusia. Badan Kepegawaian dan Pengembangan Sumber Daya Manusia Kota Tasikmalaya mempunyai tugas pokok membantu Walikota melaksanakan fungsi penunjang urusan pemerintahan daerah di bidang kepegawaian, pendidikan dan pelatihan daerah termasuk di dalamnya pelayanan kesekretariatan bagi Dewan Pengurus Korps Pegawai Republik Indonesia.

Dalam melaksanakan tugas pokok tersebut, Badan Kepegawaian dan Pengembangan Sumber Daya Manusia Kota Tasikmalaya mempunyai salah satu fungsi perumusan kebijakan teknis dalam kepegawaian, pendidikan dan pelatihan daerah dalam mengembangkan kompetensi bagi pegawai dilingkungan Pemerintah Kota Tasikmalaya termasuk di Badan Kepegawaian dan Pengembangan Sumber Daya Manusia itu sendiri. Organisasi ini dituntut untuk menghasilkan kinerja baik secara individual maupun secara kelompok.

Dalam menetapkan visi misi tujuan dan sasaran didasarkan pada isu-isu strategis yang berkaitan erat dengan tugas pokok dan fungsi Badan Kepegawaian dan Pengembangan Sumber Daya Manusia, sehingga visi dan misi program kerja dan kegiatan diharapkan mampu menyelesaikan masalah yang dihadapi. Isu Strategis yang dihadapkan oleh Badan Kepegawaian dan Pengembangan Sumber Daya Manusia adalah: 1. Jumlah pegawai masih kurang dan belum sesuai dengan kebutuhan dalam analisis jabatan dan analisis beban kerja;

2. Data basis kepegawaian belum sepenuhnya belum tersusun dengan baik;

3. Pembinaan kepegawaian berupa hukuman dan ganjaran (reward dan punishment) belum sepenuhnya dilaksanakan.

Indikator Kinerja Utama Badan Kepegawaian Pengembangan Sumber Daya Manusia KotaTasikmalaya ditetapkan melalui surat keputusan Kepala BKPPD Kota Tasikmalaya Nomor: 050/kep.479. BKPPD/ 2018 tentang Penetapan Indikator Kinerja Utama (IKU) di Lingkungan Badan Kepegawaian Pendidikan dan Pelatihan Daerah Tasikmalaya

Dalam rangka menjawab isu-isu strategis dan pencapaian visi misi Badan Kepegawaian dan Pengembangan Sumber Daya Manusia Kota Tasikmalaya diperlukan kinerja pegawai yang tinggi. Meningkatnya kinerja pegawai secara tidak langsung akan berpengaruh pada kinerja organisasi. Selain itu kinerja juga dapat menciptakan suasana yang lebih kondusif yang pada akhirnya menimbulkan persaingan yang sehat antar pegawai dan akan mempunyai dampak pada pengembangan diri pada masing-masing pegawai. Apabila kinerja pegawai dapat diwujudkan dengan baik, akan mendukung tercapainya tujuan secara efektif dan efisien karena akan menciptakan suasana percepatan pelaksanaan kegiatan di lingkungan Badan Kepegawaian dan Pengembangan Sumber Daya Manusia Kota Tasikmalaya.

Berdasarkan hasil observasi awal ditemukan ditemukan masalah dalam pelaksaaan pekerjaan pegawai pada Badan Kepegawaian dan Pengembangan Sumber Daya Manusia 
Kota Tasikmalaya seperti pada pelaksanaan program kerja masih banyak yang belum terselesaikan sehingga target pelayanan yang harus diberikan tidak tercapai. Dalam melaksanakan pengelolaan data belum sesuai aturan yang ada, karena pegawai kurang terampil dalam mengelola data sehingga belum mampu memberikan informasi data pegawai pada suatu urut kerja yang lengkap.

Selain itu pegawai jika diberikan tugas untuk menyelesaikan suatu pekerjaan tidak tepat waktu penyelesaian dokumen atau naskah dan laporan-laporan pekerjaan. Pegawai tidak menjalin kerja sama dengan rekan kerja contohnya ketika menyelesaikan pekerjaan bersama-sama hanya beberapa orang yang mengerjakan sedangkan yang lainnya tidak bekerja sehinga menimbulkan suasana kurang nyaman dalam lingkungan kerja.

Permasalahan-permasalahan yang diuraikan diatas erat kaitannya dengan kinerja pegawai. Permasalahan tersebut peneliti menduga disebabkan oleh beberapa faktor kompetensi pegawai yang terlihat dari belum mengoptimalkan para pegawai yang mempunyai potensi dalam melaksanakan tugas, seperti halnya sebagai pelaksana atau penata tugas pembinaan terhadap dan belum melaksanakan tugasnya sesuai dengan fungsi dalam menjalankan aktifitasnya.

Adanya peningkatan kompetensi sangat penting dilakukan untuk mendukung kemampuan kerja pegawai sekaligus meningkatkan kinerja pegawai, artinya semakin tinggi kompetensi seorang pegawai maka diharapkan kinerja pegawai tersebut juga akan semakin tinggi.

Kompetensi sering digunakan sebagai kriteria utama untuk menentukan kerja karyawan seperti profesional, manajerial atau senior manajer. Kompetensi Menurut (Sedarmayanti, 2012) kompetensi adalah karakteristik yang mendasar yang dimiliki seseorang yang berpengaruh langsung terhadap atau dapat memprediksikan kinerja yang sangat baik.

Lebih lanjut ia membagi gugus dan dimensi kompetensi,

1. Berorientasi Prestasi dan Tindakan;

a. Semangat untuk berprestasi dan untuk mencapai target kerja.

b. Perhatian terhadap kualitas dan ketelitian kerja.

c. Proaktif dan inisiatif.

d. Mencari informasi.

2. Membantu dan Melayani orang lain;
a. Empati
b. Berorientasi pelanggan.

3. Kemampuan mempengaruhi dan menciptakan dampak;
a. Luasnya dampak dan pengaruh.
b. Kesadaran berorganisasi.
c. Membangun hubungan kerja

4. Kemampuan manajerial;
a. Mengembangkan orang lain.
b. Kemampuan mengarahkan/memberikan perintah.
c. Kerja sama kelompok.
d. Memimpin kelompok.

5. Kemampuan kognisi; 

a. Berpikir analitis.
b. Berpikir konseptual.
c. Keahlian teknikal/ profesional/ manajerial.

6. Kemampuan efektivitas pribadi;

a. Pengendalian diri.

b. Percaya diri.

c. Fleksibilitas.

d. Komitmen Organisasi

Adanya kompetensi yang baik pada seorang pegawai diharapkan dapat meningkatkan kinerja pegawai. Menurut (Rivai Veithzal, 2010). Kinerja adalah hasil atau tingkat keberhasilan seseorang secara keseluruhan selama periode tertentu didalam melaksanakan tugas dibandingkan dengan segala kemungkinan, seperti standar hasil kerja, target atau sasaran atau kriteria yang telah ditentukan terlebih dahulu dan telah disepakati bersama.

Pengukuran kinerja karyawan diukur berdasarkan beberapa dimensi. Menurut (Mathis \& Jackson, 2012) elemen kinerja sebagai berikut :

1. Kuantitas;

2. Kualitas;

3. Ketepatan waktu;

4. Kehadiran;

5. Kemampuan bekerja sama;

Untuk menghasilkan kinerja pegawai yang berkualitas dan dapat berjalan efektif tentunya diperlukan kompetensi aparatur pemerintah daerah. Pernyataan di atas sejalan dengan kajian yang dilakukan oleh penelitian (Andini dan Yusrawati, 2015) yang menunjukkan kompetensi SDM berpengaruh terhadap kualitas laporan keuangan daerah pada SKPD Kabupaten Empat Lawang. Penelitian lain yang mendukung pengaruh kompetensi terhadap kinerja yaitu (Purnama, Catherine Kempa, Sesilya 2016) adanya pengaruh positif dan signifikan kompetensi terhadap kinerja karyawan, pada Hotel Pita Maha A Tjampuhan Resort \& Spa. Hasil penelitian lainnya yaitu penelitian (Triastuti, Dinie Anisa 2019) menunjukkan Kompetensi berpengaruh positif terhadap kinerja pegawai. Artinya jika kompetensi ditingkatkan, maka kinerja pegawai akan meningkat pula Kinerja Pegawai Pada Bank BJB Cabang Tasikmalaya.

Penelitian ini bertujuan untuk mengetahui pengaruh kompetesi terhadap kinerja pegawai di Badan Kepegawaian dan Pengembangan Sumber Daya Manusia Kota Tasikmalaya.

\section{METODE PENELITIAN}

Metode penelitian yang digunakan dalam penelitian ini metode deskriptif explimentory survey. Menurut (Sugiyono, 2011), metode deskriptif explimentory survey adalah statistik yang digunakan untuk menganalisis data dengan cara mendeskripsiskan atau menggambarkan terhadap obyek yang diteliti melalui data sampel atau populasiyang 
terkumpul sebagaiman adanya tanpa bermaksud membuat kesimpulan yang berlaku untuk umum".

Populasi dalam penelitian ini yaitu pegawai di Badan Kepegawaian dan Pengembangan Sumber Daya Manusia Kota Tasikmalaya, dengan jumlah sebanyak 56 orang. Teknik sampling yang digunakan random sampling, 36 orang pegawai. Teknik pengumpulan data dalam penelitian ini dilakukan melalui observasi, studi kepustakaan dan angket. Teknik analisis data dalam penelitian ini dilakukan melalui uji regresi sederhana, yaitu untuk mengetahui besar pengaruh kompetesi terhadap kinerja pegawai di Badan Kepegawaian dan Pengembangan Sumber Daya Manusia Kota Tasikmalaya.

\section{HASIL DAN PEMBAHASAN}

Badan Kepegawaian Dan Pengembangan Sumber Daya Manusia Kota Tasikmalaya dibentuk berdasarkan Peraturan Daerah Kota Tasikmalaya Nomor 60 Tahun 2019 tentang perubahan kedua atas Peraturan Wali Kota Tasikmalaya Nomor 40 Tahun 2016 Tentang Susunan Organisasi, Kedudukan, Tugas Pokok Fungsi dan Tata Kerja Perangkat Daerah ( Berita Daerah Kota Tasikmalaya Tahun 2016 Nomor 296). Badan Badan Kepegawaian Dan Pengembangan Sumber Daya Manusia mempunyai tugas pokok membantu Walikota melaksanakan fungsi penunjang urusan pemerintahan daerah di bidang kepegawaian, pendidikan dan pelatihan daerahtermasuk didalamnya pelayanan kesekretariatan bagi Dewan Pengurus Korps Pegawai Republik Indonesia.

Variabel kompetensi pegawai memiliki kategori baik. Kompetensi berkategori baik menunjukkan bahwa pegawai bekerja berorientasi prestasi dan tindakan, membantu dan melayani orang lain, kemampuan mempengaruhi dan menciptakan dampak yang positif dalam lingkungan kerja, kemampuan manajerial, kemampuan kognisi dan memiliki kemampuan efektivitas pribadi. Variabel kinerja pegawai memilikikategori baik. Kinerja pegawai berkategori baik menunjukkan bahwa telah bekerja dengan kualitas yang baik, kuantitas yang sesuai target, bekerja sesuai dengan yang ditargetkan, kehadiran sesuai aturan dan mampu bekerja sama dengan rekan kerja dan atasan.

Analisis korelasi dan koefisien diterminasi pengaruh kompetensi terhadap kinerja pegawai dapat dilihat pada hasil pengolahan data sebagai berikut :

Tabel 1

Besarnya Pengaruh Kompetensi Terhadap Kinerja Pegawai

Model Summary

\begin{tabular}{|l|c|r|r|r|}
\hline Model & $\mathrm{R}$ & R Square & Adjusted R Square & Std. Error of the Estimate \\
\hline 1 & $.730^{\mathrm{a}}$ & .533 & .519 & 3.73364 \\
\hline
\end{tabular}

a. Predictors: (Constant), X 
Hasil pengolahan data (terlampir) menggunakan software SPSS Versi 16 dapat terlihat pada nilai $\mathrm{R}$ sebesar 0,730 . Hal ini menunjukkan bahwa hubungan antara kompetensi (X) terhadap kinerja pegawai (Y) sebesar 0,730 termasuk memiliki hubungan yang kuat. Besar kecilnya pengaruh kompetensi $(\mathrm{X})$ terhadap kinerja pegawai (Y) dilihat dari nilai $\mathrm{R}$ square. Hasil pengolahan data menunjukkan nilai $\mathrm{R}$ square sebesar 0,533 . Hal ini menunjukkan bahwa besarnya pengaruh pengaruh kompetesi terhadap kinerja pegawai di Badan Kepegawaian dan Pengembangan Sumber Daya Manusia Kota Tasikmalaya sebesar 53,3\% dan sisanya sebesar $46,7 \%$ dipengaruhi oleh faktor lain.

Hasil penelitian ini sesuai dengan penelitian yang dilakukan (Alamsyah, Rahayu, \& Muslih, 2017) yang menunjukkan Populasi dalam penelitian ini adalah pegawai bagian akuntansi/ keuangan pada Satuan Kinerja Perangkat Daerah (SKPD) Kota Depok. Teknik penentuan sampel menggunakan metode sampling sensus, dimana semua populasi di-jadikan sample yakni sebanyak 89 orang.

Secara parsial kompetensi SDM, memiliki pengaruh terhadap kualitas laporan keuangan daerah. Berdasarkan pengujian kontribusi secara simultan oleh variabel-variabel bebas (R2) sebesar 91,2\%.Berdasarkan hasil penelitian, maka untuk meningkatkan kualitas laporan keuangan yang baik instansi meningkatkan kompetensi sumber daya manusianya, menerapkan/ mengimpelementasikan SAKD yang berlaku, memanfaatkan teknologi informasi dalam menjalankan tugas, serta menerap-kan sistem pengendalian internal yang baik dalam menciptakan suasana kerja yang baik, agar tugas yang dilaksanakan/ penyajian laporan keuangan akan semakin baik/ berkualitas.

Hasil pengolahan data uji hipotesis sebagai berikut :

Tabel 2

Persamaan Regresi kompetensi terhadap kinerja pegawai

Coefficients $^{\mathbf{a}}$

\begin{tabular}{|ll|r|r|r|r|r|}
\hline \multirow{2}{*}{ Model } & \multicolumn{2}{|c|}{$\begin{array}{c}\text { Unstandardized } \\
\text { Coefficients }\end{array}$} & \multicolumn{1}{c|}{$\begin{array}{c}\text { Standardized } \\
\text { Coefficients }\end{array}$} & & \\
\cline { 3 - 5 } & & \multicolumn{1}{|c|}{$\mathrm{B}$} & Std. Error & \multicolumn{1}{c|}{ Beta } & \multicolumn{1}{c|}{$\mathrm{t}$} & \multicolumn{1}{c|}{ Sig. } \\
\hline 1 & (Constant) & 13.505 & 3.496 & & 3.863 & .000 \\
& $\mathrm{X}$ & .385 & .062 & .730 & 6.225 & .000 \\
\hline
\end{tabular}

a. Dependent Variable: $\mathrm{Y}$

Hasil perhitungan uji t diperoleh nilai t hitung sebesar 6,255 dan t tabel sebesar 2,004 maka $\mathrm{t}$ hitung $>$ dari $\mathrm{t}$ tabel dan nilai signifikan 0,000 lebih kecil dari 0,05. Hal ini menunjukkan bahwa ada pengaruh yang signifikan kompetensi terhadap kinerja pegawai pada Badan Kepegawaian dan Pengembangan Sumber Daya Manusia Kota Tasikmalaya dijelaskan dengan faktor berorientasi prestasi dan tindakan, membantu dan melayani orang lain, kemampuan mempengaruhi dan menciptakan dampak, kemampuan manajerial, kemampuan kognisi dan kemampuan efektivitas pribadi. Hasil penelitian ini sesuai dengan penelitian (Sudibya, I Gde Adhyana Utama, I Wayan Murdiartha, 2013) kompetensi berpengaruh tidak signifikan terhadap kinerja pegawai. Kompensasi pegawai yang perlu ditingkatkan guna meningkatkan kepuasan kerja dan apabila kepuasan kerja pegawai meningkat maka kinerja pegawai juga akan meningkat di Lingkungan Dinas Pekerjaan Umum Bali. 
Kompetensi yang baik dalam hal pegawai berorientasi pada prestasi dan tindakan dalam melakukan pekerjaan, membantu dan melayani pengguna pelayanan dan rekan kerja, kemampuan mempengaruhi dal hal positif dan menciptakan dampak lingkungan kerja yang nyaman membuat meningkatkan kinerja pegawai. Selain itu kemampuan manajerial sebagai pimpinan dalam suatu kelompok kerja, kemampuan dalam membuat inoavasi dan pemikiran untuk meningkatkan kualitas serta pengendalian diri akan meningkatkan kinerja pegawai Badan Kepegawaian dan Pengembangan Sumber Daya Manusia Kota Tasikmalaya.

Susanto menjelaskan kompetensi guru secara persial berpengaruh terhadap kinerja guru SMK di Kabupaten Hulu Sungai Selatan, Kalimantan Selatan (Susanto, 2012). Selanjutnya Hasil penelitian berbeda yaitu penelitian (Supiyanto, 2015) yang menunjukkan secara parsial kompetensi tidak berpengaruh terhadap kinerja karyawan KSP (Koperasi Simpan Pinjam) yang tersebar di Kabupaten Tuban.

Kompetensi merupakan karakteristik pribadi yang mendasari seseorang dalam berperilaku di dalam melaksanakan kegiatan atau tugas pekerjaannya yang meliputi pengetahuan, keterampilan dan sikap sehingga dapat menghasilkan kinerja yang superior atau efektif. Pada dasarnya, kompetensi dan kinerja memiliki hubungan yang saling mempengaruhi. hubungan antara kompetensi dengan kinerja, yaitu: sebagai kebutuhan, tetapi bukan merupakan kondisi yang mencukupi, kompetensi tetap diperlukan untuk mendukung kinerja.

Kemudian hasil penelitian (Zarvedi, Yusuf, \& Ibrahim, 2017) menunjukkan bahwa kompetensi berpengaruh terhadap kinerja pegawai. Hasil penelitian (S.E., 2013) Hasil penelitian menunjukkan ada pengaruh positif kompetensi sosial terhadap motivasi kerja karyawan pada bagian pemasaran PT Adira Finance Singaraja. Hal ini menunjukkan bahwa Pegawai yang memiliki kompetensi berorientasi prestasi dan tindakan akan bekerja dengan teliti dan menghindari kesalahan selain itu pegawai akan mencari inforamasi tentang pekerjaan yang diembannya. Hal ini akan meningkatkan wawasan dan pemahaman pegawai untuk meningkatkan keterampilanya dalam melakukan pekerjaan.

Kompetensi berpengaruh terhadap kinerja berbeda dengan hasil penelitian (Septiyani \& Sanny, 2013) melalui pembagian kuesioner kepada karyawan PT. Beta Setia Mega menunjukkan bahwa kompetensi individu terhadap kinerja karyawan tidak berpengaruh secara parsial. Motivasi terhadap kinerja karyawan berpengaruh secara parsial. Di samping itu, kompetensi individu dan motivasi terhadap kinerja karyawan berpengaruh secara simultan.

Para pegawai Badan Kepegawaian dan Pengembangan Sumber Daya Manusia Kota Tasikmalaya tidak hanya membantu di dalam organisasi saja akan tetapi membantu para pengguna pelayanan apabila mengalami kesulitan. Para pegawai berusaha untuk mendengar apa yang disarakankan oleh rekan kerjanya. Adanya saling membantu antar rekan kerja dapat meningkatkan kuantitas kerja yang semakin banyak dan kualitas kerja yang semakin baik. Hal ini dikarenakan para pegawai saling mengingatkan apabila ada kesalahan.

Hasil penelitian (Yahya \& Hidayati, 2014) menunjukkan Pengaruh kompetensi pedagogik, kompetensi profesional, kompetensi kepribadian dan kompetensi sosial secara simultan (bersama-sama) sebesar 0,653 atau 65,3\%. Ini artinya secara simultan kompetensi pedagogik, kompetensi profesional, kompetensi kepribadian dan kompetensi sosial berpengaruh terhadap penilaian kinerja dosen sebesar $65,3 \%$ hal ini menunjukkan bahwa 
secara simultan berpengaruh signifikan. Dan pengaruh variabel kompetensi pedagogik terhadap penilaian kinerja dosen adalah sebesar 0,232 atau 23,2 \%, pengaruh variabel kompetensi profesional terhadap penilaian kinerja dosen adalah sebesar 0,120 atau $12 \%$, pengaruh variabel kompetensi kepribadian terhadap penilaian kinerja dosen adalah sebesar 0,384 atau 38,4\%, sedangkan pengaruh variabel kompetensi sosial terhadap penilaian kinerja dosen adalah sebesar 0,183 atau $18,3 \%$.

Adanya perilaku memberikan dampak positif di lingkungan kerja akan membuat suasana kerja yang nyaman yang dapat meningkatkan kinerja pegawai. Pegawai berusaha mencapai visi dan misi yang ditetapkan oleh organisasi maka pegawai diberi arah tujuan organisai yang ingin di capai sehingga pegawai fokus dalam bekerja untuk mencapai visi misi tersebut. Keinginan untuk mencapai misi misi tersebut dapat meningkatkan kinerja pegawai.

Adanya kerjasama yang baik antara pegawai dan atasan dapat meningkatkan kuantitas dan kualitas kerja dan meningkatkan kemampuan pegawai dalam bekerja. Hasil penelitain (Rahmisyari, 2017) Kompetensi (X1) dan Lingkungan kerja (X2) Terhadap Kinerja Pegawai (Y), secara simultan berpengaruh positif dan signifikan terhadap kinerja Pegawai (Y) sebesar 0,808 atau 80,8\% dan sisanya 19,2\% yang ditentukan oleh faktor-faktor lain.

Selain itu penelitian (Wirotomo \& Pasaribu, 2015) menjelaskan keberhasilan organisasi dalam mencapai tujuannya ditunjang oleh faktor-faktor internal dan eksternal organisasi, di mana untuk mencapai kinerja organisasi yang maksimal maka sisi internal organisasi yang terlebih dahulu mendapatkan perhatian. Hasil penelitian disimpulkan bahwa secara simultan kompetensi, pengembangan karir dan diklat berpengaruh positif dan signifikan terhadap kinerja pegawai. Kompetensi merupakan variabel yang paling besar pengaruhnya terhadap kinerja pegawai.

\section{PENUTUP}

Adanya pengaruh kompetensi terhadap kinerja pegawai pada Badan Kepegawaian dan Pengembangan Sumber Daya Manusia Kota Tasikmalaya dijelaskan dengan factor berorientasi prestasi dan tindakan, membantu dan melayani orang lain, kemampuan mempengaruhi dan menciptakan dampak, kemampuan manajerial, kemampuan kognisi dan kemampuan efektivitas pribadi. Disarankan kompetensi yang sudah dimiliki oleh pegawai terus ditingkatkan dengan melakukan pelatihan-pelatihan dan mengembangan diri sehingga dapat lebih meningkatkan kinerja pegawai tersebut.

\section{DAFTAR PUSTAKA}

Alamsyah, M. R., Rahayu, S., \& Muslih, M. (2017). "Kompetensi Sumber Daya Manusia, Penerapan Sistem Akuntansi Keuangan Daerah (Sakd), Pemanfaatan Teknologi Informasi, Dan Sistem Pengendalian Internal Terhadap Kualitas Laporan Keuangan Daerah (Studi Empiris Pada Satuan Kineja Perangkat Daerah (SKPD) Kota Depok". Majalah Ilmiah UNIKOM. https://doi.org/10.34010/miu.v15i2.559

Andini, D., \& Yusrawati. (2015). "Pengaruh Kompetensi Sumber Daya Manusia Dan Penerapan Sistem Akuntansi Keuangan Daerah Terhadap Kualitas Laporan Keuangan Daerah". Jurnal Ekonomi, Manajemen Dan Akutansi. https://doi.org/10.1017/CBO9781107415324.004

Mathis, R. L., \& Jackson, J. H. (2012). Human Resource Management: Manajemen Sumber Daya Manusia. In Terjemahan Dian Angelia. Jakarta: Salemba Empat. 
Purnama, C., \& Kempa, S. (2016). Pengaruh Kompetensi Dan Disiplin Kerja Terhadap Kinerja Karyawan. Journal Manajemen Manajemen.

Rahmisyari, R. (2017). Pengaruh Kompetensi dan Lingkungan Kerja Terhadap Kinerja Pegawai. Jurnal Manajemen Dan Bisnis Indonesia. https://doi.org/10.31843/jmbi.v5i1.139.

Rivai Veithzal. (2010). Manajemen Sumber Daya Manusia untuk Perusahaan dari Teori ke Praktik. Jakarta: PT. Raja Grafindo.

S.E., M. (2013). Pengaruh Pengalaman Kerja, Kompetensi Sosial Dan Motivasi Kerja Terhadap Kinerja Karyawan Pada Bagian Pemasaran PT Adira Finance Singaraja. Jurnal Jurusan Manajemen.

Sedarmayanti. (2012). Sumber Daya Manusia Dan Produktivitas Kerja: Sedarmayanti.

Septiyani, S., \& Sanny, L. (2013). Analisis Pengaruh Kompetensi Individu dan Motivasi terhadap Kinerja Karyawan PT. Beta Setia Mega. Binus Business Review. https://doi.org/10.21512/bbr.v4i1.1055.

Sudibya, I. G. A., \& Utama, I. W. M. (2013). Pegawai Di Lingkungan Kantor Dinas Pekerjaan Umum. Manajemen, Strategi Bisnis, Dan Kewirausahaan.

Sugiyono. (2011). Metode Penelitian Kuantitatif, Kualitatif dan R \& D.Bandung:Alfabeta. Metode Penelitian Kuantitatif, Kualitatif Dan $R \quad \& \quad$ D.Bandung:Alfabeta. https://doi.org/10.1017/CBO9781107415324.004.

Supiyanto, Y. (2015). Pengaruh Kompensasi, Kompetensi Dan Komitmen Organisasional Terhadap Kepuasan Dan Kinerja. Jurnal Economia. https://doi.org/10.21831/economia.v11i2.8281.

Susanto, H. (2012). Faktor yang Mempengaruhi Kinerja Guru SMK. Jurnal Pendidikan Vokasi. https://doi.org/10.21831/jpv.v2i2.1028.

Triastuti, D. A. (2019). Pengaruh Lingkungan Kerja, Kompetensi Dan Iklim Organisasi Terhadap Kinerja Pegawai. Journal of Management Review. https://doi.org/10.25157/jmr.v2i2.1796.

Wirotomo, (Dono), \& Pasaribu, (Popy). (2015). Pengaruh Kompetensi, Pengembangan Karir, Pendidikan Dan Pelatihan (Diklat) Terhadap Knerja Pegawai Direktorat Jenderal Perimbangan Keuangan. MIX: Jurnal Ilmiah Manajemen.

Yahya, Z., \& Hidayati, F. (2014). Analisis Kompetensi Terhadap Penilaian Kinerja Dosen (Studi Kasus Dosen UIN Sultan Syarif Kasim Riau). Kutubkhanah: Jurnal Penelitian Sosial Keagamaan.

Zarvedi, R., Yusuf, R., \& Ibrahim, M. (2017). Pengaruh Kepemimpinan, Budaya Organisasi Dan Kompetensi Terhadap Kinerja Pegawai Serta Implikasinya Pada Kinerja Sekretariat Kabupaten Pidie Jaya. Jurnal Perspektif Ekonomi Darussalam. https://doi.org/10.24815/jped.v2i2.6694 